\title{
Pages from a Bandmaster's Diary (Continued)
}

Author(s): George J. Miller

Source: The Musical Times, Vol. 56, No. 872 (Oct. 1, 1915), pp. 595-599

Published by: Musical Times Publications Ltd.

Stable URL: http://www.jstor.org/stable/908266

Accessed: 24-06-2016 05:43 UTC

Your use of the JSTOR archive indicates your acceptance of the Terms \& Conditions of Use, available at

http://about.jstor.org/terms

JSTOR is a not-for-profit service that helps scholars, researchers, and students discover, use, and build upon a wide range of content in a trusted digital archive. We use information technology and tools to increase productivity and facilitate new forms of scholarship. For more information about JSTOR, please contact support@jstor.org.

Musical Times Publications Ltd. is collaborating with JSTOR to digitize, preserve and extend access to The Musical Times 
Another enterprise, very different HAKESPEARE in character, but equally courageous AND and deserving, is that of the Royal Grand Opera, Victoria Hall, Waterloo Road, S.E. FROM We have received the prospectus $2 d$. UPWARDS. for the coming season, from which we learn that performances of Shakespearean and classical plays will take place on Mondays, Wednesdays, and Fridays at 7.45 , and on Wednesdays at 2.30 , from October 4 to January 14 . These are under the direction of Mr. Ben Greet. Grand Opera will be given on Thursdays and Saturdays at 7.45. Twopence admits to the gallery, while a shilling purchases a stall. The management have this year adopted a system of subscription ticket-books, each containing twenty-five. We wish the 'Old Vic.' a successful season, and suggest to sympathetic readers the purchase of a book of tickets for distribution among clubs and schools. Full particulars of the season's arrangements can be obtained on application to the lessee and manageress, Miss Lilian Baylis, at the Hall.

Last month we mentioned our A GOOD MUSIC-HALL depressing experience of the inanity and vulgarity of the "entertainment" presented at a 'first-rate' metropolitan music-hall. We now note TURN. the commendable enterprise of the Coliseum (which was not the hall we visited) in engaging Madame Kirkby Lunn as one of its star turns. The Coliseum has done a great deal to encourage British musical art, and deserves reciprocal support.

Elsewhere we give the announceSYMPHONY ments issued by the London CONCERTS. Symphony Orchestra and the Royal Philharmonic Society. By these schemes, with which the ubiquitous Mr. Beecham is closely associated-the Queen's Hall Saturday Afternoon Concerts-metropolitan audiences will during the winter be provided with at least two orchestral concerts of the best description every week. No doubt the Sunday Societies that organize orchestral concerts will also resume their usual activities.

It is a notable and curious fact 'SOME' OPERA. that in these times there is to be an unusual output of opera performances. The gratifying aspect of the 'boom' is that entrepreneurs appeal not to society patronage but to the ordinary public, who pay their money and expect to get their money's worth by being provided with what they like. First there is the admirable scheme devised by Mr. Thomas Beecham and Mr. Robert Courtneidge, which will be inaugurated at the Shaftesbury Theatre on October 2, when Gounod's 'Romeo and Juliet' will be given. All the performances will be in English. Then as we write we have the Carl Rosa Company at the Marlborough Theatre, the Moody-Manners Company at Croydon, and the D'Oyly Carte Company at Hammersmith. Besides all these operatic activities, there are Mr. Frewin's Company and the O'Mara Opera Company in being. This outburst should pave the way to something important. Incidentally these laudable enterprises provide engagements for numerous British performers, and for this reason alone it may be hoped that they will be successful.

The British Bandsman has given forty-three lists of civilian bandsmen who have enlisted, the total number amounting to 5,833. This is a splendid record. The names of ninety-five who have fallenfallen for us-have also been given.
PAGES FROM A BANDMASTER'S DIARY.

By Major George Miller.

(Continued from September number, p. 537.)

IN MEMORIAM.

In 1895 the band (R.M.L.I., Portsmouth Division) had a 'busman's holiday, being for five weeks a-soldiering on the Army mancuvres. The weather was glorious, and notwithstanding the fact of being physically untrained the men and I managed to 'stick it' and have a real good time. We returned home as hard as nails and fit for anything-except to play stringed instruments. It was therefore with some musical misgiving that I found an order awaiting us to play during and after the Queen's dinner at Osborne on the following day. The Court had arrived for its regular August visit.

In accordance with the usual custom the band played there about once a week, and one afternoon the cricket team went over and played a match against the Royal servants. There was nothing to 'write home about' in all this of itself, but Fate was at work, and the occasion was destined to prove memorable, for it was the last we were to see of His Royal Highness Prince Henry of Battenberg.

The Prince was intensely fond of music; he had a keen delicacy of perception, but never posed as a musician. He played the violoncello in private and played fairly well, but was too nervously sensitive to grind away at exercises and therefore did not excel. 'When from the first position I shift to the fourth and the note comes not, I can no more.' There is only one instance on record of his emerging from his shelllike reserve, and that is in connection with the Isle of Wight Volunteers. The occasion was a Mess dinner given by Colonel Cradock and the Officers to the Prince on his becoming Colonel of the Regiment, when the music was provided by a small orchestra scraped together by Captain Sweetman, who himself struggled with the violoncello parts. It was after dinner, and Sweetman was still struggling, when Prince Henry came up to him and said: "Sweetman, I do not play the violoncello very well, but I play better than you. Shall I play that?' Sweetman admits that the provocation was very great.

Previous to his marriage, the Prince had no intimate knowledge of British bands; their economic conditions were entirely strange to him. Continental military systems provide ready-made professional musicians to fill vacancies as they occur; it is for the bandmaster simply a matter of selection from amongst the conscripts of his own regiment. But when a vacancy occurs in our bands the bandmaster has to do the best he can, and under a system of voluntary enlistment it is not an easy matter to maintain a decent state of efficiency, especially in the case of the string band, which is a sort of amateur affair, a second study undertaken by the men for pure love of it. Prince Henry was much interested to know all this, and at once became sympathetic and helpful ; he considerably extended our knowledge of musical literature, and at his own expense contributed to our repertory. There are certain delicious old-time Strauss valses, for instance, whose acquaintanceand idiomatic appreciation we owe entirely to him.

To return to the August of '95. I thought that the Prince was unwell; he was restless and spoke of a long yachting trip in the Sheila, and he consulted me as to the possibility of engaging a small band to go with him to the Mediterranean. What followed is a matter of history - trouble broke out in West Africa, the yachting trip was put off, and the Prince joined the expeditionary force as a volunteer. 
He was still in West Africa and not very well in health when the Court returned for the New Year. The usual Twelfth Night tableaux, in which Prince Henry used to take an active part, were abandoned but later in the month (January, I896), when reassuring news came along, theatricals were arranged and the band was sent for. The usual round of musical duty was in full swing, we had been there three days, when with tragic suddenness came the report of the Prince's death, and the next programme in which the band took part was of a very different character.

The funeral music was selected by the widowed Princess, and the ceremonial was dictated by H.R.H. the Duke of Connaught.

Funeral of

H.R.H. Prince Henry of Battenberg, K.G. Wednesday, 5th February, 1896.

MUSICAL ARRANGEMENTS.

Isle of Wight Volunteers (Princess Beatrice's Own)
Mr. G. Hatfield, Bandmaster. Scottish Rifles (Cameronians)

Mr. A. R. V. Laverock, Bandmaster.

Royal Marine Light Infantry(Portsmouth Division) Mr. George Miller (Mus. Bac.) Bandmaster.

The Pipers of the Scottish Rifles (Cameronians) under Pipe-Major Macdonald.

The Drummers of the Royal Marine Light Infantry (Ports. Div.) under Drum-Major E. Keen.

Order of Formation - I. Volunteer Band.
2. Pipers.
3. Scottish Rifles Band.
4. R.M.L.I. Drummers.
5. R.M.L.I. Band.

On the Procession starting from Trinity Pier-

Funeral March on Muffled Drums by R.M.L.I. Drummers (32 paces).

I. 'Marcia Funèbre sulla morte d'un eroe' Beethoven R.M.L.I. Band.

2. 'Crossing the Bar' (Bridge) and 'Blest are the departed ' (Spohr)

Scottish Rifles Band.

3. 'Flowers of the Forest'

Cameronian Pipers.

4. Funeral March $\begin{gathered}\ldots . . \\ \text { Volunteer Band. }\end{gathered}$

5. Solemn March (composed for the occasion)

R.M.L.I. Band.

George Miller

6. Scottish Funeral March 'Oran an doig' ... Sommer Scottish Rifles Band.

7. Lament (on the death of a chief) Cameronian Pipers.

8. Funeral March (Farewell) ...

9. Funeral March (from the 'Lieder öhne Worte')

R.M.L.I. Band.

After each of the above (Funeral Marches) the R.M.L.I. Drummers play an Interlude on Muffled Drums (during 32 paces)

On arrival at the Church the whole of the Bands (massed) play the Chorale 'Jesus, meine Zuversicht' (Krüger, I653)

After the Ist volley-A Short Roll by the whole of the Drummers (massed) with drums unmuffled.

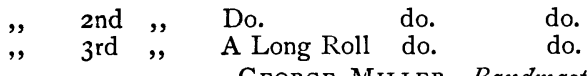

'I, TOO, AM A MUSICIAN.'

The custom after the Queen's dinner, at Osborne, was for the band to move to the terrace, where devotees of the post-prandial cigarette assembled. One evening in August (1889), after the Royal Princes and their guests had returned to the House, a solitary individual remained. He was dressed in the uniform of a Naval Lieutenant and appeared much interested in the band's performance even to the extent of going the round of the bandstands and watching individual musicians at their work. The piece over he introduced himself by saying, 'I, too, am a musician. There's nothing like music, is there ?' with which, of course I very heartily agreed. 'Then, we will shake hands,' and he warmly suited the action to the words.

A conversation on instrumental music ensued, on terms of perfect equality, for no old bandmaster could have talked with better technical knowledge or with greater enthusiasm.

Finding that I knew very little of foreign bands, he gave a very ample dissertation, clearly proving that he had intimate knowledge of the bands of every nation on earth, and wound up (as was expected from a British Naval Officer) by saying that British bands excelled especially by reason of their composition, and also that they had an additional advantage in the high pitch, this being in his opinion much better for open-air playing. German and Austrian Military bands were better, no doubt, for purely military work, but for purposes such as that in which we were then employed, the wealth of the English reed instruments gave an undeniable advantage. He then startled me by asking if I could manage to play for him one or two real English Hornpipes! Perceiving my perplexity he said, 'You think I am English, but I am a Prussian,' explaining that he spoke our language well because his mother was English. We played him the hornpipes from my "Voyage in a Troopship.' He thanked me and suggested an exchange, a copy of my piece for a composition of his.

'I suppose if I send my piece to Portsmouth addressed to you, it will find you? Well then, good-night.'

He shook hands, and turned to go.

'Good-night, but how and where will my piece find you ?'

And in the same easy, everyday manner, he replied :

'Oh ! I forgot. I am Henry of Prussia, and if you send it here, it will find me.'

\section{SOUSA.}

The admissions to the Glasgow Exhibition of I90I amounted to the colossal total of II,497,220. The 'show' had run smoothly from start to finish and had been worthy in every way, so that all Glasgow from the Lord Provost downwards was very justly proud and elated at the City's enterprise and its reward. The attendance on the last day was 173,266 , chiefly composed of ardent spirits bent on giving the bands a good send-off.

The excitement on such occasions reaches a climax at the time 'God Save the King' is played for the last time. It is not an altogether pleasant experience to be lifted off your feet, your arms and legs seized by 'ardent spirits,' probably entire strangers to you and to one another, and not one of them having a definite idea of what he wants to do or where he wants to go. And as this was the prospect in store for us, Sousa and I readily agreed to a suggestion of Manager Hedley's and were spirited away by the police. The bandsmen did not escape so easily, and there was subsequently 
quite a long tale of damages for torn uniforms, lost caps, bruised instruments and so forth. 'But 'twas a glorious victory,' and the management readily paid the bill ; so readily in fact as to leave a private regret on the parts of some of the claimants. Sousa's black servant 'William' was the object of particular attention when it was realised that Sousa himself had gone. William, however, was equal to the occasion. Surrounded on all sides and finding escape impossible, he himself seized on the nearest man, mounted his back, twined his long arms and legs around him with the grip of an octopus, and never let go until well out of the melée. 'And I had the best carry I ever had since I was a baby' was William's laughing summary of the experience. It is to be doubted whether the other chap, the bearer of the burden, enjoyed it as much, for William was a huge, hefty, Jack-Johnson of a nigger, and had held tight. Gentle reader, you may never be in like demand at the hands of a GlasgowExhibition-closing-night crowd, but you will, when doing your grand tour, sometimes be attacked by donkey-boys, touts, cochers, interpreters, guides and other licensed loafers, and you will find William's tactics worth remembering.

My band played at that Exhibition in all for five weeks, so that I had the unusual luck of being able to enjoy the society of, what the Navy calls, the 'opposite number.' As a rule, bandmasters pass each other 'like ships in the night.' It was lucky also that that opposite number should be Sousa, for the association was both pleasant and profitable. He taught me, by example of course, a few things in the art of pleasing people (as was to be expected), and he taught me many things in what might be called militarism (which was not to be expected, observing that my band was a military organization whereas his was not). For Sousa's band was a model in smartness, accoutrement from head to foot, discipline and demeanour. It was presentable alike in a hot concert room or outside, great-coated, in a cold bandstand; every member keen and responsive to the conductor's slightest hint. And all these things as well as the thousand-and-one other things which made for the success of 'Sousa and his band' were of Sousa himself. I have never found a more complete illustration of genius, according to Carlyle's definition ; for Sousa's capacity for detail was infinite. Among his other qualities was that of being a delightful companion when out of the motley, being especially charming by reason of his personal modesty.

Sousa was none the less a genius for not being extraordinarily clever in an academical sense. He had written books of travel and adventure, and also (I believe) of fiction, but did not claim to be ranked as an author. He wrote a light opera, words and music, staged and stage-managed it, produced and toured it, and all without claiming to be a Gilbert, a Sullivan, or a George Edwardes. (The spirit of 'El Capitan' still romps and frolics in the 'revue' of to-day.) Nor did he claim to be a great conductor ; and the fact of his stage-tricks being taken seriously was as good a joke to Sousa the musician as it was to other musicians. The chief merit in his celebrated marches lay in their straightforward simplicity, and all he himself asked was that they should be judged by results-their effect upon people and things. "I tell you, the very cobbly stones around our Barracks used to curl around when we'd strike up "Semper Fidelis" coming home from exercise. For I was once a Marines bandmaster, like you, and at a concert correctly played my piece for ten minutes, then sat quiet and thought on my family affairs for five minutes, then another piece, and so on. But there was no money in it, so I struck out for myself.'
He was not only the architect of his own fortunes, but found his own constructive materials, and he built up 'Sousa's Band 'until. like Harrods' Stores, Pears' Soap, and Beecham's Pills, it became immortal, a superstition, a world-wide belief, a realisation of the potentialities of a concept and the useful art of putting two and two together.

Sousa was a world-caterer, and his commodity was cheerfulness. To run in for an hour or so to one of his concerts was even as a swizzly drink on a long hot day, and I wonder how many millions of blue devils have been routed and put to flight by the irresistible slap-bang of the 'Washington Post' as played by Sousa and his band.

GERMAN BANDS.

The Band was on duty at Osborne in '89, when the new German Emperor 'on promotion' paid a visit to the Queen. He arrived in his royal yacht, with an escort of German warships, the crews of which must have been largely composed of bandsmen. (This is quite possible, remembering the nature and conditions of German naval and military service.) For shore purposes an enormous band of from sixty to eighty was employed, and according to the cap-ribbon it belonged to the Second (Wilhelmshaven) Division. The dress was that of the junior naval petty officers, and the men looked very smart in their shell jackets and brass buttons. Wohlbier, a fine-looking Prussian with a full beard and a presence, was the chief bandmaster; he was a warrant officer ranking 'with but after' the assistant engineers and paymasters.

The playing of the band was well in tune, precise, even brilliant at times, but very mechanical, perfunctory, and soulless, and, 'God forgive me! I never was so little pleased with a Concert of Music in my life' (Pepys). Let an orchestral musician imagine a Queen's Hall Concert with half its usual quota of string players and he will be able to form some idea of the effect of a Prussian regulation-military band (Infanterie-Music) playing a miscellaneous programme. British Bandmasters divide their personnel about equally between reeds and brasses. German bandmasters have no voice in the matter, but have to conform to regulations which give a huge preponderance to brass instruments. Consequently the reeds, being overweighted, have to over-blow to make themselves heard at all. (I have related elsewhere a story of Prince Henry of Prussia which can be read in this connection.)

Wohlbier and I used to meet in the quarters and under the friendly auspices of Campbell, the Queen's piper. Wohlbier was loquacious, and told us lots of interesting things. How 'Unser Wilhelm' had brought over several cases full of decorations for all and sundry, something ' with crossed swords' for these peoples, something 'without swords' for those peoples. The favours were to extend to bandmasters, and there was one even for myself. Then Wohlbier questioned us as to the British decorations which would be given in return, what, for instance was 'ze Bad.' Campbell replied, 'Quite good.' So Wohlbier consented to be satisfied with a K.C.B. But the schemes of the piper's room went badly 'agley,' for in effect Wohlbier received a tie-pin bought in Ryde for the purpose, and Campbell and I received nothing. There was "nothing doing' in decorations, and so the boxes were carted back to Germany unopened. The Emperor, however, was created an Admiral of the Fleet and Colonel-inChief of the First Royal Dragoons, and the Queen graciously accepted the Colonelcy of a Prussian regiment, a circumstance which led to my next experience of German Bands. 
In 189 , one of the continental 'star turns' at the South Kensington Exhibition was the band of the 'Zweite-Garde-Dragoner Regiment, Königin von Gross-Brittannien und Irlande,' and a cold-blooded, unimaginative London public wondered, and was disappointed to find that it was only a cavalry brass band of the Prussian regulation strength of twentyfive. It compared, therefore, in point of numbers, with the 'champion' brass bands of Yorkshire and Lancashire. It did not excel those doughty heroesof-a-thousand-contests in personal prowess, but the constitution of the band was better in some respects, inasmuch as soprano and alto trumpets and flugelhorns, used in addition to cornets, gave a tone variety which was new to us. The tenors and basses however did not come up to Bellevue Gardens standard, either in quality or variety. My adjudication on the whole would have been a win on a narrow margin of points in favour of the John Willies, coupled with the suggestion that they still had something to learn.

At the close of the Exhibition the band of the 'Zweite' (taken as read) was on a loose end. An expected invitation to spend a week at Osborne, in attendance upon its Colonel-in-Chief, had not fetched up. Obviously it had 'miscarried,' and so the bandmaster acted in accordance with his original instructions and came on as far as Portsmouth. There the Zweiters were stopped by His Royal Highness the General Officer Commanding, and presumably not knowing what else to do with the party, it was handed over to the Marines.

Accustomed as the Corps is to odd jobs, this was a bit of a poser, but the Commandant, Colonel Moody was quite equal to it. Quarters were found in Forton Barracks, evening engagements on Southsea Pier, and the Zweiters had an all-round good time. Carl Voigt (informally known as 'Papa' Voigt), the bandmaster, was a fine old soldier, who as a trumpeter had sounded the charge and been wounded at Königgratz. He also served throughout the FrancoPrussian War. The remainder were all young fellows, professional musicians, putting in their compulsory period of service, two years, I think, in a comparatively soft job. The visit lasted for the best part of a week, and a short time afterwards the Marines Sergeants, the band, and I, each received a souvenir in the form of a large photograph of the band on horseback, with the veteran bandmaster at its head, inscribed 'Zur freundlichen Erinnerung an die mit unsern guten Camaraden der Marine Light Infantry verlebten Täge in Gosport.' (Signed) Carl Voigt, Königliche Musik-Dirigent, $Z$ weite (as before).

Subsequent to the Imperial visit in ' 89 the German Emperor visited Osborne more or less regularly for the Cowes yachting week, and according to whether the visit was to be regarded as official, semi-official, or otherwise, so the strength of the attendant band varied. The visit of ' 93 was one of importance, because it was dignified by the presence of the full band of the First or Kiel Division under Herr Pott ; in its orchestral phase a remarkably fine band, but in its military combination on a par with that of the Wilhelmshaven band already described.

The last entry in my diary relating to a German band is dated November, I907. This band belonged to the royal yacht, and was not very strong in numbers, only about forty, but was very good, particularly in its orchestral aspect. The practice of calling upon one or other of the Divisional bands for yacht service had been discontinued, and the 'Hohenzollern' now had a band of its own with a smart young bandmaster (Pollinger) in charge. We exchanged musical courtesies and improved each other's repertory, they giving us a Sarabande of
Handel and we giving them a Prelude of Bach. Their manner of doing it was particularly graceful, as each bandsman copied his own part, signed it, and presented it to his opposite number in my band. On leaving the port they sent us a photograph of the band, a big box of cigars, a sailor's cap-band, and a letter. The cigars promptly went in smoke, but the photograph, cap-band, and letter remain. The letter was in English-as-she-is-with-lexicon-little-helping geschrieben, and is exactly as follows :

\section{Devotion.}

The capelle of the yacht 'Hohenzollern' will you give an little present of LEgitivate German smokings. To remembrance of the pleasure hours witch we have had be they, allowed we us to give our capband, with the please its in the room of the corporal-camerads hanging up.

In the hope we you see again very well saluted.

Die Kapella. S.M.Y. 'Hohenzollern,'

Portsmouth, I3th Nov., 1907.

SANDHURST AND SULLIVAN IN THE EARLY'EIGHTIES.

The old college-building was architecturally nothing to boast of, but it was planted in a perfectly ideal spot, the southern corner of Windsor Forest, and the plainness of the edifice simply enhanced the beauty of its surroundings. After four years in Central India, with only a sheet of brown paper between us andthe hottest of all places, the change of appointment came as a veritable salvation, especially as during those awful years my wife had had one long struggle for bare life and I myself had been none too well.

The actual pay was not attractive, but the duties were simple and straightforward and did not extend beyond the college terms: moreover, 'better fifty years of Europe than a cycle of Cathay.' During vacations, in common with all the other residents, one either frolicked or hibernated, according to the weather.

I took up my duties at the beginning of a term. The bandsmen that day were acting as detectives or special constables, for a particularly enterprising set of cadets had to be dealt with. The previous term had ended in something approaching disorder. There had been a battle-royal with the Blackwater gipsies; the cadets had been gated, had then put the field-guns in the lake, and the Duke of Cambridge had been down specially to talk fatherly to them.

The bandsmen 'doubled' the duties of postman and buglers. There were some twenty of them, fine old soldiers, but they did not relish practice at any time, and openly rebelled against it during vacation. (I was officially rebuked for making such an attempt.) The band duties consisted of short programmes of one hour's duration, either in the afternoon during cricket, football, or whatever sport might be going on, or in the evening at one or other of the messes.

Besides the Governor, there were only two executive officers - the Commandant and the Adjutant. The latter was not exactly the beau-ideal of an adjutant, for he wore easy boots and walked circumspectly, and also had an impediment in his speech. His drill was peculiar and parochial, as : 'No. I Company will fall in on the third window,' or 'Under-officers will salute on passing the grating.' Away from the college precincts, someone else (probably one of the professors) would take charge, for Adjutancy, in fact, was the least of his many vocations. When he died there was a general upheaval, the old order changed entirely, and several grand old veterans, each with a history like a Ouida novel, were replaced by others, less picturesque but more up-to-date.

The Commandant, one of the old school, was musical to the extent of possessing a tenor voice. Its compass was well within the limits of the stave, and no power on earth could move him to an endeavour to extend 
it. As the Governor was musically a non-starter, it devolved upon the Commandant to undertake the principal tenor parts in social musical functions, and he accepted the duty like the fearless old warrior that he was, and tackled the job in the true-blue, do-or-die spirit. But he took no unnecessary risks. 'One $G$ is surely as good as another, so why go a purler over the top of the confounded five-barred gate when you can get through the hedge an octave lower ?' and he used to re-arrange his 'part' with the help of one finger on a piano. The melodic results were very peculiar.

There was plenty of musical talent among the cadets. Two instances were remarkable. One I discovered 'seated one day at the organ,' the college organ forsooth, and very 'ill at ease' at being caught, for a report would have meant severe punishment. But he told me his story, and oh! the pity of it. He was the son of a clergyman, had all his life been passionately fond of music, had never had a chance of indulging it, the one pianoforte in his home belonged to an elder sister and he was sternly forbidden to touch it, a friendship struck up with his father's organist had been peremptorily nipped in the bud, and his only enjoyment had been to listen to his sister's practice or the organist's performances. These became indelibly fixed in his mind. 'I will play you almost anything,' and he enumerated a long list of standard compositions. I chose the Mendelssohn Wedding March, and he played it absolutely correctly as to melody and harmony, but in the key of C sharp! Asked if he knew that the key was wrong he replied 'Yes, but I play everything in black keys; they are so much easier than white keys.' He then explained that he used to risk a licking and practise on his sister's pianoforte when his people were out, and sometimes get at the church organ with the secret connivance of the organist.

Another man (whose parents also should have been hanged) was more remarkable still, seeing that in addition to melody and harmony he had the gift of absolute pitch and key-colour. 'Please, Mr. Bandmaster, will you come to my room and I will play you some things from Sullivan's new opera which I heard last night.' He sat down to a pianoforte and talking, singing or whistling at the same time, played several numbers perfectly: "I have got the right hand of several other numbers, but shall have to go again to get my left hand right.' In a week or two, he had the whole opera off with both hands, and in the original keys.

$\mathrm{He}$, even as the other man, did not know B from a bull's foot, or how to finger a scale. And these young gods wanted me to teach them 'Music'!

The Royal Military College Choral and Orchestral Society was the product of the later, regenerate times. Thanks to the enthusiasm and genius of the Lady Jane Taylor, it soon became well established both in numbers and efficiency, and it is (I believe) still going strong. It brought not only experience but some very welcome grist to the 'Miller.' Another contribution was from the Dripping Fund, in cash not in kind, for training a string band out of the college bandsmen. Also I presided at the organ. It could not be said that I played that organ, for that organ and I had a serious difference in the early days of our acquaintance from the shock of which I never thoroughly recovered. It was thiswise. One Sunday evening I became so touched, so thoroughly absorbed in the sermon that I forgot to look at the registering, and the 'Amen' came, not as the coo of the sucking dove but as the roar of ten thousand bulls of Basan, and then in my fright, I had stood on the pedals!

That organ, however, did me a remarkably good turn later, for it was the means of bringing me into acquaintanceship with Arthur Sullivan, who was then in the very zenith of his popularity; the said popularity was, in fact, part of the scheme. Sullivan knew Sandhurst intimately from the time when his father held my own appointment of bandmaster there ; and he used sometimes to escape from the vortex of London and bury himself, incognito, in the environment of his childhood, making his headquarters in a neighbouring village inn of stage-coach repute. His wanderings had one night taken him into the chapel, where I found him amusing himself with the organ. I knew him well by sight from my own old Glasgow Choral Union days, when he sometimes conducted. $\mathrm{He}$, for his part, remembered my father, and so we got on, and continued to get on very well until one Sunday morning someone peeped behind the screen when Sullivan was surreptitiously playing the organ for me at a parade service, and there were thereafter no peaceful week-ends for him, or delightful tête- $\grave{c}-$ têtes for me.

\section{GERMAN MUSIC.}

The following letter from Sir Charles Stanford appeared in the Morning Post of September $2 \mathrm{I}$ :

I venture to think that your conclusions as to Wagner and Brahms representing modern Germany are far from being correct. These composers are in reality the last representatives of the German classical school. Wagner, the descendant of Gluck and Weber ; Brahms, the descendant of Beethoven and Schumann. Neither had anything typical of modern Prussianised Germany about him. Wagner was the anti-Prussian revolutionary of 1848 , and, in his later years, at all events, was an outspoken admirer of England, as I well remember from his visit in 1877 , and the many interesting things, sympathetic to this country, which he said to his host, Dannreuther. He would have been the first to pour contempt upon his posthumous son-inlaw, Chamberlain.

Brahms was so typically un-Prussian that he chose Vienna as his home, and went to Berlin as seldom as possible. He openly, at the Grand Duke of Meiningen's dinner table, upheld the cause of Japan against China, in the teeth of the official German support of the latter, foretold the success of Japan at the outset of the war, and that, when it was over, Germany would step in and prevent Japan from reaping the fruits of her victory. When the Grand Duke answered : 'You forget, Brahms, that we have interests to safeguard,' Brahms, banging the table with his fist, ejaculated : 'And you, a respectable (anständiger) Prince of Germany, and you talk like that!' The incident was related to me shortly after it took place by one who was at the dinner table. I was in Berlin when the German Emperor sent the telegram to Kruger, and heard myself Brahms's dislike of it, expressed very clearly in Joachim's study.

Neither Wagner nor Brahms had any truck with the Prussianised crew who have arisen since their day. To identify the 'frightfulness' of Strauss and the mass formations of Reger with either of them is an insult to them and to their work for musical art. We can no more ignore them than we can Goethe and Schiller. But the beastliness of modern hypnotised Germany was neither of their time nor of their nature. To obliterate their works in England is to cut off our noses to spite our faces. To do so will not hurt present-day Germans at all, though it may give them cause for a little consoling and not ill-founded merriment. On the other hand, it is good policy to show that we are more perspicacious and discriminating than they are themselves in retaining the old artistic work and rejecting the modern muck which they themselves pose as preferring.

I hold a letter from one of the soundest, ablest, and most revered of living French musicians, which breathes a far nobler sentiment than the boycotting of works which the world has, up to 1914 , accepted as great. Let it not be forgotten that Paris after 1870-7 I continued to perform without interruption the operas of Meyerbeer, who only seven years before was the official head of the Royal Opera House at Berlin. 